\title{
DESCRIPTIVE-TEXT TEACHING MATERIALS BASED ON LOCAL WISDOM IN THE BORDER AREA FOR JUNIOR HIGH SCHOOL STUDENTS
}

\author{
Giri Indra Kharisma ${ }^{1}$, Imaniah Kusuma Rahayu ${ }^{2}$ \\ ${ }^{1,2}$ Indonesian Education and Literature Study Program, Faculty of Education, Timor University \\ Jalan El Tari Km 09, Timor Tengah Utara, East Nusa Tenggara \\ Corresponding Author: indrakharisma@unimor.ac.id
}

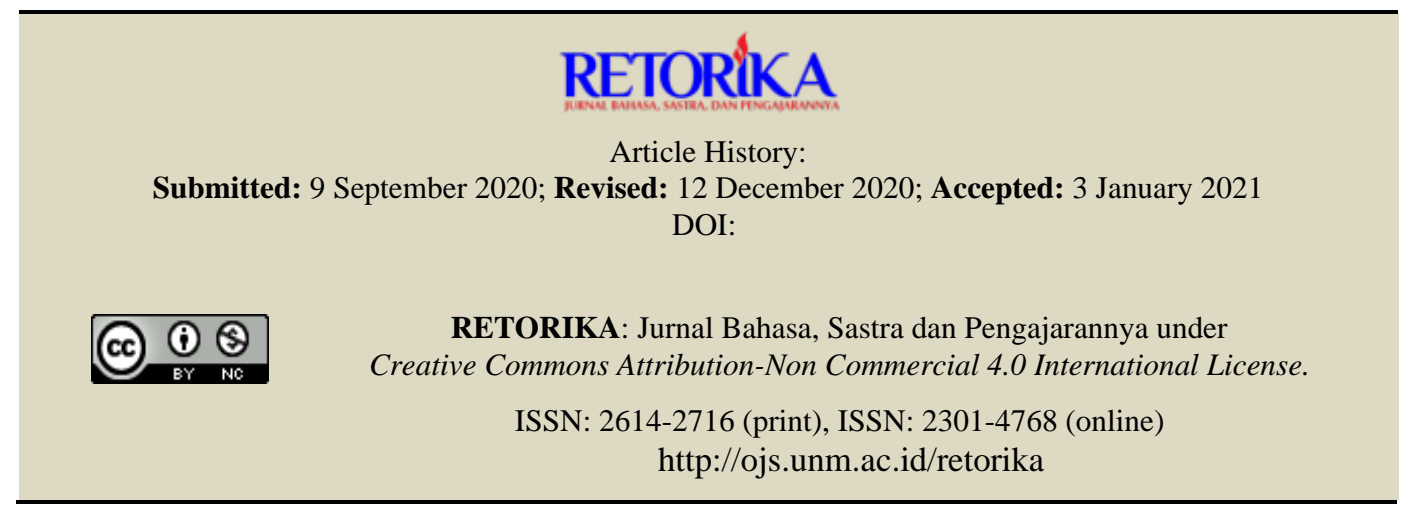

\begin{abstract}
The product of this research is in the form of a textbook which aims to facilitate students in learning to understand and to produce descriptive texts. All the reading passages presented in the textbook describe the local wisdoms in Belu, which is directly adjacent to Timor Leste. This research uses 4D development model consisting of 4 stages, namely: define, design, develop, and disseminate. Based on the validation results by experts and practitioners, the developed textbook had a percentage of higher than $85 \%$ with a very feasible category to be implemented. The results of the try-out of the product conducted on students showed a very good response because it obtained $92 \%$ feasibility with a very good category.
\end{abstract}

Keywords: teaching materials, descriptive text, local wisdom, border area

Teaching materials in the form of textbooks are considered to be a practical learning tool because they are able to facilitate students to learn independently. Theoretically, textbooks are arranged according to the learning needed by students in the form of specific and systematic units or activities based on the applied curriculum (Subadiyono, Supriyadi, Erlina, Petrus, \& Gadeng, 2017). The practicality of textbooks also lies in the presentation of the learning material which has been specifically designed according to the context of the teaching and learning activities in the classroom. In the classroom learning activities, teachers can directly teach the learning material by following the learning activities arranged in the textbooks or adapting the learning activities in the textbooks according to the Lesson Plans (RPP). In addition, textbooks should provide various learning exercises for each basic competency that must be learned by students. This will certainly be very helpful for students to understand the learning material demanded by the curriculum, both in the classrooms and at home.

Teaching materials, as one of the learning components, should also be able to facilitate character education in schools. Character edu- 
cation attempts to develop cultural values and national character in students (Raharjo, 2010). Students are expected to have these values and apply them in their own lives, so that they can become religious, nationalist, productive, and creative individuals. Therefore, teaching materials should provide learning materials, illustrations, and themes that are able to reflect the vision of character education.

Learning materials can be used as a way to develop students' character by integrating the learning materials with the local wisdom. Local wisdom is defined as a view of life and knowledge from certain communities to solve various problems in their lives (Sutriyati, Mulawarman, \& Hudiyono, 2019). This means that local wisdom contains noble virtues, most of which is still traditional. According to Alwasilah et al (2009: 50), a number of traditional educational practices have proven effective in solving life problems and preserving the environment. This is in accordance with the spirit of character education.

Integrating the learning materials with the local wisdom is also a way to preserve the local wisdom itself. This becomes crucial in that the local wisdom of various regions in Indonesia seems doomed to extinction due to modernization. Local wisdom that generally bears traditional characteristics is often unable to survive the current of modernization. Moreover, some people have an assumption that local wisdom is a primitive culture, thus making the community anti-local wisdom. Such views will certainly accelerate the extinction of local wisdom which, in fact, contains a lot of good values.

Nowadays, the local wisdom in the border area between Indonesia and Timor Leste is increasingly alarming. The impact of massive modernization and the influence of culture from neighboring countries have increasingly eroded the existence of local wisdom in border areas. Local wisdom, which generally bears traditional characteristics, has begun to be considered outdated and obsolete. In addition, the lack of efforts to preserve the local wisdom in the border areas may cause the local wisdoms in these areas to be claimed by neighboring countries.

Belu district is one of the districts which are directly adjacent to Timor Leste. It is stated that the government will make Belu district as the center of economic growth in the border area
(Edon, 2020). Therefore, enough attention should be given to the tourism sector in order to improve the economy of this region. The community in this area particularly needs to actively participate in introducing and preserving local tourism and culture in Belu. In addition, Belu has enchanting natural and cultural beauty such as: white sandy beaches, savanna, historic fortresses, and traditional houses. One of the efforts that can be done to introduce and preserve the local tourism and local wisdom in Belu district is by integrating it into Indonesian language learning activities in schools.

The Indonesian language and literature learning (PBSI) in the 2013 curriculum is designed as text-based learning. The text is seen as a social process that is oriented towards particular social goals and in the context of particular situations (Priyatni, 2013: 65). The students are initially asked to understand various texts and then to produce them. After the students are able to produce the texts, the students are expected to be able to implement it in various language activities in everyday life in accordance with social goals and the situational contexts.

One of the learning materials that should be taught in junior high school level based on the 2013 curriculum is descriptive text. Maria Nova \& Sumadi (2017) state that descriptive text is a text that describes something according to its actual state, so that readers can imagine (see, hear, smell, and feel) the described object in accordance with the image of the writer. Similarly, Lestari (2018) states that the descriptive text is a form of essays which describes something as clearly as possible, so that the readers seem to be witnessing or experiencing it himself. As a whole, a descriptive text describes particular objects that are built through the writer's various sensory impressions, so that they are able to make the readers feel what the writer feels. Therefore, the descriptive text is the appropriate text to convey the local wisdom in Belu.

The elaboration of the arguments above becomes the reason for developing descriptive text teaching materials based on the local wisdom in border areas for junior high school students. The purpose of these teaching materials is not only to teach students to understand and to produce descriptive texts, but also to introduce and to preserve local wisdom in border areas and instill character education through descriptive texts. The descriptive text is chosen to be the 
developed teaching materials because it is able to clearly describe the local wisdom in Belu, so that it can raise students' awareness to preserve, introduce, and apply local wisdom in the border area.

Many researches on the development of teaching materials based on local wisdom have shown effective results. The research conducted by Sarjono Owon (2017) with the title Pengembangan Bahan Ajar Menulis Berbagai Jenis Teks Bertema Kearifan Lokal Sikka bagai Siswa SMP (Developing Teaching Materials on Writing Various Text Types with Sikka Local Wisdom Theme for Junior High School Students) shows that the developed prototype obtained an average score of 77.45 from the expert validation, so that it was declared feasible. Moreover, the results of the user validation obtained an average score of 85.53 with very feasible category. Lestariningsih \& Suardiman (2017) have also developed thematic-integrative teaching materials based on local wisdom to increase students' awareness and responsibility characters. The results of the expert validation indicated that the developed teaching materials were feasible for use. The results of the research also showed that the developed teaching materials were effective in improving students' awareness and responsibility characters.

\section{METHOD}

This research uses the Four-D (4D) development model from Thiagarajan, Dorothy, and Melvyn which has 4 stages, namely: define, design, develop, and disseminate (Nadatul Aisyi, Muti'ah, \& Edi Pornomo, 2018).

In the define stage, the specifications of the product were determined based on the results of a needs analysis and curriculum review. The needs analysis was carried out by using a questionnaire for teachers to reveal the obstacles that the teachers found when teaching descriptive texts in schools, especially related to the use of teaching materials. In addition, teachers were also asked to give suggestions about the local wisdom in Belu district that students needed to learn. In addition, the curriculum review was done to determine the basic competencies, the learning indicators, the learning presentation processes, and the learning evaluations that would later be presented in the teaching material product.
After the define stage completed, the next stage was the design stage. The design stage began with collecting information about the local wisdom in Belu (observation). The obtained information was then used to produce descriptive texts. In addition, the researchers also collected images, supporting applications, and various other main aspects. After the descriptive texts and the other learning materials were ready, an initial draft of the teaching materials was made. The draft was then designed and refined by setting the layout, drawings, and coloring. The result of the design was the prototype of the teaching materials.

The next stage was the development stage. At this stage, the developed prototype of the teaching materials was validated (asked for responses and assessments) by experts on Indonesian language learning, experts on local wisdom of Belu district, and practitioners (subject teachers). In addition, the prototype was also tried out to 30 class VII students of SMPN 2 Atambua junior high school. The responses and assessments from the experts and students were then used to determine the feasibility of the teaching materials in accordance with the criteria listed in table 1 . The teaching materials were also revised according to these responses.

If the teaching material product were declared feasible, the next stage, the dissemination stage could begin. At this stage, the teaching materials were first submitted to obtain an ISBN, and then disseminated via Google Playstore in order that it could be widely implemented in schools.

The data in this development research consisted of verbal data and numerical data. The verbal data were obtained from the results of the questionnaires given to the experts, practitioners, and students. Moreover, the numerical data were obtained from the assessment results by the experts, practitioners, and students which were provided in the questionnaire. The results of the overall data analysis were used as a consideration for revising the teaching material product. In addition, the results of the analysis also determined the follow-up action and the feasibility qualifications of the teaching material product produced.

There were two data collection instruments in this research, namely the primary instrument and the secondary instrument. The primary 
instrument consisted of a prototype of the developed teaching materials and the lesson plans equipped with the rubric (profile) for the assessment of the descriptive text learning. The secondary instrument was in the form of a questionnaire that was used in the needs analysis stage, validation of experts and practitioners, and product try-out for students.

The data of this research were analyzed using qualitative and quantitative techniques. The qualitative data analysis was carried out by recording the responses from the experts, practitioners and students collected from the questionnaire. These responses were used as a reference for designing and revising the developed product. Whereas, the numerical data in the form of product assessments from the experts, practitioners, and students were analyzed quantitatively.

The results of the respondents' data were then interpreted according to the guidelines in the table below.

Table 1. Product Feasibility Criteria

\begin{tabular}{ccc}
\hline Percentage & Qualification & Follow-up \\
\hline $\begin{array}{c}85 \%- \\
100 \%\end{array}$ & Very feasible & Implementation \\
\hline $75 \%-84 \%$ & Feasible & $\begin{array}{c}\text { Implementation } \\
\text { with minor } \\
\text { revisions }\end{array}$ \\
\hline $55 \%-74 \%$ & Fairly & $\begin{array}{c}\text { Revisions } \\
\text { feasible } \\
\text { and practitioner } \\
\text { notes }\end{array}$ \\
\hline$<55 \%$ & Not feasible & $\begin{array}{c}\text { Revision with } \\
\text { alteration/Major } \\
\text { Revisions }\end{array}$ \\
\hline
\end{tabular}

\section{FINDING AND DISCUSSION}

\section{Findings}

The product developed in this research is descriptive text teaching materials based on local wisdom in the border area for class VII junior high school students. The teaching material is in the form of a textbook which aims to facilitate students in learning to understand and to produce descriptive texts. The learning activities in this book are inductively presented in order that students are able to find knowledge independently through guided exercises. Therefore, this book contains abundant exercises.
All of the descriptive text models presented in this book describe the local wisdom in Belu District, which is located directly adjacent to the Democratic Republic of Timor Leste (RDTL). There are five local wisdoms presented in this book, namely (1) Padang Fulan Fehan, (2) the traditional house of the Bunak tribe, (3) Benteng 7 Lapis (7 layer fortress) at Makes Hill, (4) Mauhalek Waterfall, and (5) Atapupu White Sand Beach. From the five local wisdoms, spiritual and social values are obtained which are used as character education for students. These values include: (1) remembering the greatness of God's creation, (2) gratitude to God Almighty, (3) preserving ancestral culture, and (4) tenacious.

The material presented in this book is based on the revised 2013 curriculum. The basic competencies that become the basis of the developed teaching materials are: (3.1) Identifying information in the descriptive texts about objects (schools, tourist attractions, historical places, and/ or local art performances) that are heard and read; (4.1) Explaining the content of the descriptive texts about objects (tourist attractions, historical places, regional art performances, traditional fabrics, etc.) that are heard and read, written, and visualized; (3.2) Examining the generic structure and language of the descriptive text about objects (schools, tourist attractions, historical places, and/ or local art performances) that are heard and read; and (4.2) Presenting data, ideas, impressions in the form of descriptive texts of objects (schools, tourist attractions, historical places, and/ or local art performances) in both written form and oral form by considering the structure and the language of the texts.

The structure of this book is made up of three main sections, namely the front matter, the body matter, and the end matter. The front matter includes eight parts: (a) cover, (b) title page, (c) copyright page, (d) preface, (e) table of contents, (f) list of figures, (g) presentation of book contents, and (h) revised 2013 curriculum. The explanation for the front matter section is described as follows.

First, the cover. The cover of this teaching material contains the author's name, the title of the teaching material, the educational unit level, and a picture as the background. Look at the figure 1 !

In figure 2, the names of the book authors are written in the upper right corner. In the middle of the book cover is the title of the book and the 
educational unit level, namely: JELAJAHI BATAS NEGERI Buku Penunjang Bahasa

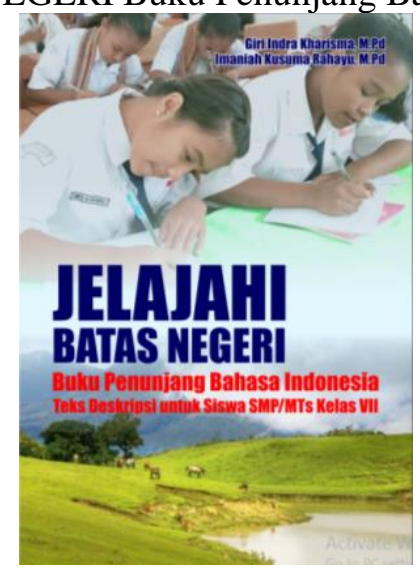

Figure 1. Book Cover

Indonesia Teks Deskripsi untuk Siswa SMP/ MTs Kelas VII (EXPLORE THE BORDERS OF THE COUNTRY Supporting Books Indonesian Language Descriptive Text for Class VII SMP/ MTs Students). In addition, a picture is used as the background for the title and authors' names. The picture depicts junior high school students writing and Padang Fulan Fehan, which is one of the iconic tourist attractions in Belu District.

Second, the title page. The title page also includes the authors' names, the book title, picture, and the name of the book publisher, namely LPPM IAI Ibrahimy Genteng Banyuwangi. Third, the copyright page. This section contains the book title, author names, ISBN number, editor, book designer, publisher, year of publication, and copyrights. Fourth, the preface. This section contains gratitude for the completion of this book, the purpose of this book, an overview of the contents of the book, and acknowledgements to those who have supported the publication of this book. Fifth, the table of contents. This section aims to inform readers about the chapters and subsections presented in the book sequentially based on page numbers.

Sixth, the list of figures. This section aims to inform the readers about what figures are presented in the book and are placed sequentially according to page numbers. Seventh, the presentation of the book contents. This section contains an explanation of the features contained in the book along with an extract of each feature. The goal is to make it easier for students to use this book. Eighth, the revised 2013 curriculum. This section contains Core Competencies (KI) and Basic Competencies (KD) in the revised 2013 curriculum which is used as the basis for presenting the teaching material in this book.

The body matter of this book contains the teaching materials, which are divided into 4 units, each unit representing a different basic competency. Unit A presents Basic Competency (KD) 3.1 which contains the learning material identifying information in descriptive texts. Unit B presents Basic Competency (KD) 4.1, which contains summarizing the contents of descriptive texts. Unit C presents Basic Competency (KD) 3.2 which contains the learning material about the generic structure and language feature of descriptive texts. Unit D presents Basic Competency (KD) 4.2 about producing descriptive texts.

Each unit in this book has several features, namely: (1) introduction, this section is the opening unit in which there are illustrations, foreword, and learning objectives. Learning objectives serve as targets that need to be achieved by students at the end of the learning activities, (2) initial exercise, this section contains easy exercises to stimulate students' initial competences or prior knowledge, so that they are better prepared to do the main exercises. Initial exercises can be done individually or in groups, (3) main exercise, this section contains guided exercises for achieving learning objectives in each basic competency, (4) advanced exercise, this section contains independent exercise to strengthen students' mastery of the learning material in each unit or basic competency. This exercise can be done at home or after the learning activities at schools, (5) inspiration column, this section involves spiritual or social valuescontained in the descriptive text presented in each unit. It functions to facilitate character education for students to have noble character, (6) you need to know! This section is placed at the end of each unit which contains a summary of the learning material to complement or support students' understanding of each basic competency in each unit, (7) reflection, this section is at the end of the unit which aims to find out the extent to which students understand the learning material in each unit. In this section students are asked to write down the learning material that has been understood during the learning activities, and to write down any questions related to the learning material that they have not understood. 
Each unit in this book is provided with several exercises, which are divided into three parts, namely initial exercise, main exercise, and advanced exercise. These exercises are arranged based on the basic competencies and the learning objectives. The following is an explanation of each exercise in each unit.

Unit A has eight exercises, two in the initial exercise, five in the main exercise, and one in the advanced exercise. The first exercise asks students to determine the location of cultural and tourist objects in Belu. This exercise also asks students to write interesting things about the objects if they have ever visited them. The Second exercise asks the students to determine the type of the descriptive text. The activity in this exercise is to match the title of the descriptive text with the type of object being described. The third exercise asks the students to read a descriptive text model entitled Fulan Fehan: Permadani Hijau di Tanah Atambua (Fulan Fehan: Green Carpet in Atambua Land). The fourth exercise is a reading comprehension test by matching the suitable information with the content of the descriptive text. The fifth exercise asks the students to determine the objects described in the model text by including evidence in the form of excerpts taken from the model text. The sixth exercise asks the students to determine sensory impressions (as if seeing, hearing, or feeling) the object described. The seventh exercise asks the students to determine the characteristics of the information in the descriptive text. In this exercise the students practice deducing the characteristics of information in the descriptive text by themselves based on the model text provided. The eighth exercise is an advanced exercise that should be done independently at home. In this exercise, the students are asked to find descriptive texts from various sources, and then they have to fill out the worksheets provided in the text book.

Unit B has ten exercises, three in the initial exercise, six in the main exercise, and one in the advanced exercise. The first exercise asks the students to arrange scrambled descriptive sentences into a good paragraph. The second exercise is a gap filling exercise where the students have to fill the gaps in the incomplete descriptive sentences. The third exercise asks the students to express their personal impressions of the images presented in the book. The fourth exercise asks the students to read a descriptive text model entitled Keunikan dan Kesederhanaan Rumah
Adat Suku Bunak (The Uniqueness and Simplicity of the Bunak Tribe Traditional House), and then the students should answer reading comprehension questions based on the text. The fifth exercise asks the students to determine the suitable information in accordance with the content of the text. The sixth exercise asks the students to give their personal responses towards sentence excerpts taken from the descriptive text model. The seventh exercise asks the students to tell interesting things that they find from the descriptive text. The eighth exercise asks the students to collect additional information from various sources about the topics presented in the descriptive text model. The ninth exercise asks the students to work in groups and make clippings from additional information obtained in the previous activity. After that, the students present the results of their clippings in front of the class. The tenth exercise is an advanced exercise. This exercise asks the students to find descriptive texts from various sources, and then fill out the worksheets provided in the book.

Unit $\mathrm{C}$ has twelve exercises consisting of two initial exercises, nine main exercises, and one advanced exercise. The first exercise asks the students to find the synonyms of the underlined word in the descriptive sentences. The second exercise asks the students to describe an object using the provided words. The third exercise asks the students to read a descriptive text model entitled Benteng 7 Lapis di Bukit Makes (7 Layer Fortress at Makes Hill). After the students finish reading the text model, they are asked to list the important information in the text model based on its structure. The fourth exercise asks the students to explain the structure of the descriptive text by determining the statements that correspond to the characteristics of the information in each structure. The fifth exercise asks the students to examine the structure of the descriptive text citation. The sixth exercise asks the students to determine the detail sentence on the object described in the descriptive text model. The seventh exercise asks the students to look for sentences that contain figure of speech in the descriptive text model that has been read. The eighth exercise asks the students to determine the synonym of the word contained in the citation of the descriptive text. The ninth exercise asks the students to determine whether a word is included as adjectives, nouns, or verbs from the list of words provided. In addition, the students are also 
asked to make a sentence from these words. The tenth exercise trains the students to use (di) as prepositions and affixes. The eleventh exercise trains the students to use capital letters correctly. The twelfth exercise asks the students to do independent practice at home by looking for descriptive texts from various sources, and then determining the generic structure and the language features of the text.

Unit $D$ has four initial exercises, three main exercises, and one advanced exercise. The first exercise asks the students to determine the object described by answering the questions provided. The second exercise trains the students to create an attractive title for the descriptive text based on a predetermined object. The third exercise trains the students to make detail sentences based on the objects contained in the previous sentence. The fourth exercise is a guessing game where the students have to guess the name of the object being described by the other student in front of the class. The fifth exercise trains the students to make an outline for a descriptive text by listing ideas based on the text structure. Before listing the ideas, the students are asked to choose the object to be described. The options for the objects include tourist attractions, traditional houses, regional arts, heirlooms, or traditional foods that the students can find in their own environment. The sixth exercise trains the students to make descriptive sentences based on the ideas that have been listed. The seventh exercise asks the students to develop the outline of their descriptive text into a complete descriptive text by paying attention to the generic structure and the language features of a descriptive text. The eighth exercise trains to students to check and give feedbacks on other students' writing based on the assessment criteria provided in the book. After that, the students improve their descriptive text based on the feedbacks given by their friends.

After the students finish improving their descriptive writing, they should publish their work on social media accompanied by pictures or videos. The goal of this activity is to make students learn to introduce the tourist attractions and culture of their region.

The end matter of this book consists of a bibliography, author's biography, and back cover. The bibliography contains a list of references used to compile this book. The author's biography contains the author's identity, work history, educational background, and publication history. The back cover of the book includes the title of the book, an overview of the contents of the book, the name and address of the publisher, and the ISBN number. In addition, the pictures of Mauhalek Waterfall and Padang Fulan Fehan are used as the cover background.

The teaching material product was validated by an Indonesian language learning expert (A1), a Belu local wisdom expert (A2), and practitioners $(\mathrm{P})$ of Indonesian language subject teachers. The validation encompasses four aspects, namely: (1) systematic aspect of writing, (2) content, (3) graphics, and (4) local wisdom. The following is a description of the validation results from experts and practitioners.

\section{The Validity of the Systematic Aspect of Writing}

In the systematic aspect of writing, five aspects were assessed by Indonesian language learning experts (A1) and practitioners (P). The following are the four aspects along with the results of the assessment by experts and practitioners.

The data in table 2 show that the total score from $\mathrm{A} 1$ and $\mathrm{P}$ for all the five aspects was 38 from the total maximum score of 40 . From this score, the overall percentage is $95 \%$. This shows that this textbook, viewed from the systematic aspect of writing and language aspect, was very feasible to be implemented because each aspect obtained a percentage of more than $85 \%$. Nevertheless, some suggestions were still given by A1 regarding the technical instructions for the learning in order to be made clearer.

\section{The Validity of Content Substance}

In this content substance, there are four aspects assessed by the Indonesian language learning experts (A1) and practitioners (P). The four aspects involve: (1) the accuracy of the theory, (2) the completeness of the material, (3) the depth of the material, and (4) the learning aspect. The results of the assessment from A1 and $\mathrm{P}$ can be seen in table 3 .

The data in table 3 show that the four aspects obtained a percentage of more than $85 \%$. This means that based on all the assessed aspects, the teaching material was very feasible to be implemented. Nevertheless, some suggestions were given from A1 regarding the completeness 
of the material, depth of the material, and learning activities. According to A1, several learning activities were not quite specific to describe the basic

Table 2. Validation Results of the Systematic Aspect of Writing

\begin{tabular}{|c|c|c|c|c|c|c|}
\hline Aspect & A1 & $\mathbf{P}$ & $\sum \mathbf{x}$ & $\sum \mathbf{x i}$ & $\mathbf{P i}$ & Description \\
\hline \multicolumn{7}{|l|}{ Systematic Aspect of Writing } \\
\hline $\begin{array}{l}\text { a. The main components of this teaching material have } \\
\text { been arranged in a good order. }\end{array}$ & 4 & 4 & 8 & 8 & $100 \%$ & Very feasible \\
\hline b. Consistency of the presentation of teaching materials & 4 & 4 & 8 & 8 & $100 \%$ & Very feasible \\
\hline c. Balance of content between chapters and sub-chapters. & 3 & 4 & 7 & 8 & $87.5 \%$ & Very feasible \\
\hline \multicolumn{7}{|l|}{ language aspects } \\
\hline $\begin{array}{l}\text { a. The material is delivered using simple, straightforward } \\
\text { and communicative language. }\end{array}$ & 4 & 4 & 8 & 8 & $100 \%$ & Very feasible \\
\hline $\begin{array}{l}\text { b. Instructions and exercises are conveyed logically and } \\
\text { communicatively }\end{array}$ & 4 & 3 & 7 & 8 & $87.5 \%$ & Very feasible \\
\hline Total & & & 38 & 40 & 95\% & \\
\hline
\end{tabular}

competencies $(\mathrm{KD})$ and learning objectives. In addition, the exercises in the book needed to be enriched and sharpened. Therefore, several activities were added to this book in accordance with the expert feedbacks. The additional activities include (1) reflection on learning in each unit, (2) training to collect additional information and to make clippings in unit B, (3) listing important information in each text structure in unit $\mathrm{C}$, and (4) training to determine the object to be described in unit D.

Table 3. Validation Results of the Content substance

\begin{tabular}{lcccccc}
\hline \multicolumn{1}{c}{ Aspects } & $\mathbf{A 1}$ & $\mathbf{P}$ & $\sum \mathbf{x}$ & $\sum \mathbf{x i}$ & $\mathbf{P i}$ & description \\
\hline a. theoretical accuracy & 8 & 7 & 15 & 16 & $93.7 \%$ & Very feasible \\
b. completeness of material & 6 & 8 & 14 & 16 & $87.5 \%$ & Very feasible \\
c. depth of material & 12 & 11 & 23 & 24 & $95.8 \%$ & Very feasible \\
d. learning activity & 15 & 16 & 31 & 32 & $96.8 \%$ & Very feasible \\
\hline \multicolumn{1}{c}{ Total } & & & $\mathbf{8 3}$ & $\mathbf{8 8}$ & $\mathbf{9 4 . 3 \%}$ & \\
\hline
\end{tabular}

\section{Validity of Book Graphic}

There were nine points assessed by A1 and $\mathrm{P}$ based on the book graphic aspect. The nine aspects involved (1) display format, (2) the appropriateness between the cover and content, (3) attractiveness of the cover, (4) attractiveness of book titles, (5) relevance of images, (6) relevance of illustrations, (7) typography, (8) color composition, and (9) the dynamic of the teaching material components. The results of the assessment can be seen in table 4 .

Table 4 shows that the nine aspects obtained a total score of 67 from a maximum score of 72. From this figure, the overall percentage was $93.05 \%$ which means that the nine aspects obtained a very feasible category to be implemented.

Several suggestions were received from A1 regarding the graphic aspect. A1 recom- mended that the identity of the subject be displayed on the cover. In addition, the presentation of the table needs to be adjusted to enable students write answers directly in the book. Moreover, A1 also suggested that the book title be revised from JELAJAHI BATAS NEGERI DENGAN DESKRIPSI: Buku Ajar Teks Deskripsi untuk SMP/MTs Kelas VII into JELAJAHI BATAS NEGERI DENGAN DESKRIPSI: Buku Penunjang Bahasa Indonesia Teks Deskripsi untuk Siswa SMP/MTs Kelas VII. Furthermore, it was also suggested that the size of the tables in the book be adjusted to accomodate the students writing their answers directly in the book.

\section{The Validity of Local Wisdom}

There are four aspects assessed by the expert of Belu Local Wisdoms (A2) related to 
the local wisdoms presented in this book. The four aspects involved: (1) the accuracy of the local wisdom theories, (2) the authenticity of the local wisdoms, (3) the usefulness and the

Table 4. Validation Results of the Graphic Aspect

\begin{tabular}{lcccccc}
\hline \multicolumn{1}{c}{ Aspect } & A1 & $\mathbf{P}$ & $\sum \mathbf{x}$ & $\sum \mathbf{x i}$ & Pi & Description \\
\hline $\begin{array}{l}\text { a. Display Format } \\
\text { b. the appropriateness between the cover }\end{array}$ & 4 & 4 & 8 & 8 & $100 \%$ & Very Feasible \\
$\quad$ and content & 4 & 8 & 8 & $100 \%$ & Very Feasible \\
$\begin{array}{l}\text { c. attractiveness of the cover } \\
\text { d. attractiveness of book titles }\end{array}$ & 3 & 3 & 6 & 8 & $75 \%$ & Feasible \\
e. relevance of images & 4 & 3 & 7 & 8 & $87,5 \%$ & Very Feasible \\
f. relevance of illustrations & 3 & 4 & 7 & 8 & $87,5 \%$ & Very Feasible \\
g. typography & 4 & 3 & 7 & 8 & $87,5 \%$ & Very Feasible \\
h. color composition & 4 & 4 & 8 & 8 & $100 \%$ & Very Feasible \\
i. the dynamic of the teaching material & 4 & 4 & 8 & 8 & $100 \%$ & Very Feasible \\
\hline$\quad$ Total & 4 & 4 & 8 & 8 & $100 \%$ & Very Feasible \\
\hline
\end{tabular}

attractiveness of the local wisdoms, and (4) the local wisdom variances presented in this book. The results of the assessment can be seen in table 5. The data in table 5 show that the four aspects of local wisdoms obtained a total score of 34 from the maximum score of 36 . Each aspect obtained a percentage of more than $85 \%$, so that each aspect was categorized as very feasible. This is supported with the statements from A2 in the questionnaire that the local wisdoms presented in this book have been well described.

Table 5. The Validation Results of the Local Wisdom Aspects

\begin{tabular}{lccccc}
\hline \multicolumn{1}{c}{ Aspect } & $\mathbf{A 2}$ & $\sum \mathbf{x}$ & $\sum \mathbf{x i}$ & $\mathbf{P i}$ & Description \\
\hline The accuracy of the local wisdoms & 8 & 8 & 8 & $100 \%$ & Very feasible \\
The authencity of the local wisdoms & 11 & 11 & 12 & $91,7 \%$ & Very feasible \\
$\begin{array}{l}\text { The usefulness and the attractiveness of } \\
\text { the local wisdoms }\end{array}$ & 7 & 7 & 8 & $87,5 \%$ & Very feasible \\
\begin{tabular}{l} 
The local wisdom variances \\
\multicolumn{1}{c}{ Total }
\end{tabular} & 8 & 8 & 8 & $100 \%$ & Very feasible \\
\hline
\end{tabular}

The teaching book that has been validated by the experts and practitioners was then tried out to 30 class VII students of SMPN 2 Attambua Junior high school. On the product try-out, the students were asked to fill out a questionnaire to assess four aspects of the book, namely (1) the systematic aspect of writing, (2) content, (3) language, and (4) layout. The following is the results of the students' assessment or responses.

Based on the data in table 6 , the total score of the answers from 30 students was 1546 from the total maximum score of 1680 . From this figure, it was obtained that the feasibility percentage was $92 \%$ with very feasible catagory from the students' point of view as the users of the book.

Table 6. Students' Assessments on the Teaching Book

\begin{tabular}{|c|c|c|c|c|}
\hline Aspect & $\sum \mathbf{x}$ & $\sum \mathbf{x i}$ & $\mathbf{P i}$ & Description \\
\hline The systematic aspect of writing & 214 & 240 & $89,1 \%$ & Very feasible \\
\hline Content & 328 & 360 & $91,1 \%$ & Very feasible \\
\hline Language & 218 & 240 & $90,8 \%$ & Very feasible \\
\hline Layout & 786 & 840 & $93,5 \%$ & Very feasible \\
\hline Total & 1546 & 1680 & $92 \%$ & \\
\hline
\end{tabular}




\section{Discussion}

The results of the validation and classroom try-out from the Indonesian Language learning expert, Belu local Wisdom expert, practitoiners, and the students of SMPN 2 Attambua Junior high school show that the descriptive text based on Belu local wisdom teaching book obtained an assessment percentage of more than $85 \%$ on each aspect. This means that the teaching book is very feasible to be implemented for the descriptive text learning in schools, especially in Belu district, which is in the border area between Indonesia and Timor Leste.

This book is intended to be additional or complementary teaching material for the Indonesian textbook provided by the government. As a complementary book, this book should certainly have several advantages in teaching descriptive texts compared to the Indonesian books from the government. First, this developed book uses contextual learning by providing reading texts that are close to the students' environment. All the reading texts presented in this book describe Belu local wisdom so that students can understand the information and values contained in the texts more easily. The use of reading texts which discuss the topic around the students' environment can also increase studetnts' interest in learning, because the topics presented are familiar to students. This is in accordance with contextual learning objectives that help students see the meaning of the academic material they are studying by linking academic subjects to their daily lives, namely in their personal, social and cultural contexts (Perwitasari, Wahjoedi, \& Akbar, 2018).

Moreover, this book is inductively developed with guided activities presented in the form of exercises. This can be seen from the description of the book which presents guided exercises starting from the initial exercises, main exercises, to advanced exercises. Through these guided activities, students are given the opportunity to do meaningful exercises through the process of experiencing, so that they are able to find knowledge independently. Students are given the opportunity to not only learn the theories about descriptive texts, but also practice reading and writing descriptive texts. It also aims to reduce language learning that focuses too much on theories, resulting in students being less skillful in using the language. According to
Priyatni \& Wahono (2012), mastering language theory does not automatically mean having good abilities in using the languages. They further explain that language skills must be trained, modeled, and practiced.

An activity-based text book is considered suitable to train students' skills in using a language, especially in the descriptive text learning. This is supported with the assessment results on the learning aspects which obtained a percentage of $96,8 \%$ from the Indonesian learning expert and practitioners. These Indonesian learning expert and practitioners state that the learning activities in this book are designed to make students actively find knowledge, not passively given knowledge.

This book not only teaches descriptive texts but also facilitates students to introduce and preserve their local wisdoms. This can be seen from the exercise in Unit D that trains the students to describe the tourist attractions, traditional houses, local art, heirloom, or traditional food from their own environment. The results of their writing will be published in students' social media accounts. Such book design is in accordance with the Indonesial Language learning objectives in the 2013 curriculum, which is to preserve national culture.

\section{CONCLUSION}

The textbook entitled JELAJAHI BATAS NEGERI: Buku Penunjang Bahasa Indonesia Teks Deskripsi untuk Siswa SMP/ MTs Kelas VII is the product of this development research. The goal of this textbook is to facilitate students to understand and to produce descriptive texts. All the reading texts presented in this book describe the local wisdoms of Belu district, which is located in the border area between Indonesia and Timor Leste.

The four aspects of this book, which involve: (1) organization and structure o writing, (2) content substance, (3) graphic, and (4) local wisdom have been validated by Indonesian language learning expert, Belu local wisdom expert, and practitioners. These four aspects obtain a percentage of more than $85 \%$, so that it is catagorized as very feasible to be implemented. The results of the product try-out, which was carried out to 30 class VII students of SMPN 2 Attambua junior high school also show very 
good responses. This is indicated from the total score of the students' responses in the questionnaire which reach 1546 from the total maximum score of 1680 . From this figure, the feasibility percentage reaches $92 \%$, which is catagorized as very feasible.

\section{Acknowledgement}

The completion of this research report is due to the contribution of thoughts and energy from various parties. Therefore, we would like to thank the Director of DP2M Dikti that has funded this research. We also thank the LPPM Univer-

\section{REFERENCES}

Alwasilah, A. C. dkk. (2009). Etnopedagogi Landasan Praktek Pendidikan dan Pendidikan Guru. Bandung: Kiblat.

Edon, M. (2020). Tito Karnavian: Wilayah Perbatasan di NTT Harus Jadi Pusat Perekonomian. Indonews.id,https://indonews.id/artikel/30476/ Tito-Karnavian-Wilayah-Perbatasan-di-NTTHarus-Jadi-Pusat-Perekonomian/

Lestari, N. D. (2018). Pembelajaran Autentik dalam Menulis Teks Deskripsi. Efektor. https://doi. org/10.29407/e.v5i2.12079

Lestariningsih, N., \& Suardiman, S. P. (2017). PeNgembangan Bahan Ajar Tematik-Integratif Berbasis Kearifan Lokal untuk Meningkatkan Karakter Peduli dan Tanggung Jawab. Jurnal Pendidikan Karakter, 7(1). https://doi.org/10. 21831/jpk.v7i1.15503

Maria Nova, M., \& Sumadi, S. (2017). Karakteristik Teks Deskripsi Siswa Kelas VII SMP. BASINDO: Jurnal Kajian Bahasa, Sastra Indonesia, dan Pembelajarannya. https://doi. org/10.17977/um032v1i22017p001

Nadatul Aisyi, A., Muti'ah, A., \& Edi Pornomo, B. (2018). Bahan Ajar Menulis Teks Prosedur Berbasis Kitab Safinatunnajah di Lingkungan Pesantren. RETORIKA: Jurnal Bahasa, Sastra, dan Pengajarannya. https:// doi.org/10.26858/ retorika.v11i2.6213 sitas Timor that has facilitated the conduct and the completion of this research. Wec also thank the reviewers who have provided input and feedbacks for the improvement of this research product. Furthermore, we also thank the practitioners, school principals, teachers, and class VII students of SMPN 2 Atambua junior high school who have been willing to be the subjects of the try-out of the developed product. It is expected that the findings of this research can give benefits for Indonesian language learning, especially for the descriptive text learning for junior high school levels and the culture in Belu District.

Perwitasari, S., Wahjoedi, \& Akbar, S. (2018). Pengembangan Bahan Ajar Tematik Berbasis Kontekstual. Jurnal Pendidikan: Teori, Penelitian, dan Pengembangan.

Priyatni, E. T., \& Wahono, A. S. (2012). Model Penyusunan Bahan Ajar Membaca Berbasis Pendidikan Multikultural dan E-Learning. Litera.

Raharjo, S. B. (2010). Pendidikan Karakter sebagai Upaya Menciptakan Akhlak Mulia. Jurnal Pendidikan dan Kebudayaan. https://doi.org/ 10.24832/jpnk.v16i3.456

Sarjono Owon, R. A. (2017). Pengembangan Bahan Ajar Menulis Berbagai Jenis Teks Bertema Kearifan Lokal Sikka bagi Siswa SMP. JINoP (Jurnal Inovasi Pembelajaran). https://doi.org/ 10.22219/jinop.v3i1.4318

Subadiyono, S., Supriyadi, S., Erlina, E., Petrus, I., \& Gadeng, R. (2017). Pengembangan Buku Teks Membaca Kritis. BAHTERA : Jurnal Pendidikan Bahasa dan Sastra. https://doi.org/10. 21009/bahtera.161.05

Sutriyati, S., Mulawarman, W., \& Hudiyono, Y. (2019). Pengembangan Bahan Ajar Menulis Esai dengan Memanfaatkan Kearifan Lokal Melalui Pembelajaran Berbasis Proyek (PBP) Siswa SMA. Diglosia. https://doi.org/10.308 72/diglosia.v2i1.16 